\title{
AN ANNOTATED LIST OF THE ANTS OF THE SNAKE RIVER PLAINS, IDAHO (HYMENOPTERA :FORMICIDAE)
}

\author{
By A. C. COLE, JR. \\ Twin Falls, Idaho
}

The ants of the Snake River Plains region, while comprising relatively few forms in comparison with other areas, are, however abundant in so far as the number of colonies is concerned. Floristically, the region is divided into (1) the vast semidesert plains of sagebrush, rabbitbrush, greasewood, shadscale and bromegrass; (2) the tall perennial grass upland habitats, in which grow the Agropyrons and Stipas and subalpine meadow vegetation; and (3) the mountainous and hilly areas, chiefly inhabited by western yellow pine, with juniper and alder at slightly lower elevations.

\section{Pogonomyrmex occidentalis Cresson ${ }^{1}$}

This is the dominant and most abundant ant of the semidesert areas. It usually builds pebble mounds with cleared surrounding area. Winged forms appear from late June to late July. Food consists of seeds of many plants although chiefly those of Bromus tectorum L. (Downy Bromegrass) when present. Crater nests of Dorymyrmex pyramicus are occasionally on the mound faces and in the denuded areas.

\section{Pheidole californica Mayr.}

This ant is abundant in sagebrush areas of the Snake River Canyon but decreases in number with northward progression, being only occasional in the tall grass meadows. It nests beneath rocks, usually on hillslopes. Colonies are rather populous. Soldiers are present, in proportion to workers about one to ten. Food consists chiefly of small seeds and some insects. Winged forms appear in August.

${ }^{1}$ Determinations and checkings by Dr. M. R. Smith. 
3. Pheidole oregonica Emery

$P$. oregonica occupies the same habitats as does $P$. californica, but its colonies are usually less populous.

4. Leptothorax curvispinosus rugatulus Emery

This ant is rather frequent in moist habitats near Twin Falls, Hagerman and Buhl, chiefly along the Snake River. Colonies are small, the workers timid and sluggish and the brood scant. Winged forms appear at Twin Falls in late September.

\section{Leptothorax eldoradensis Wheeler}

The species eldoradensis occurs in small numbers near Twin Falls, where it occupies small crater nests in moist areas.

\section{Monomorium minimum Buckley}

Occurring in small numbers, this species occupies either minute crater-nests or nests beneath fallen timber and loose rocks. The populous colonies often contain several queens each. Winged forms appear in the nests from the middle of June to late August.

7. Monomorium pharaonis L.

One colony of this species was found under a house near Twin Falls. This locality is decidedly out of its normal range.

8. Solenopsis molesta Say

This ant is occasionally found beneath rocks in moist habitats throughout southern Idaho, and is usually observed in the superficial nest chambers of other ants (Formica fusca subsericea and $F$. fusca neorufibarbis Emery).

9. S. molesta validiuscula Emery

Much more abundant than the typical species, colonies of this variety are widely scattered throughout the region under discussion, but make their appearance only in moist areas. The nests are similar to those of the typical molesta but are more isolated and of smaller size. 


\section{Manica mutica Emery}

One colony of this ant was observed beneath a large rock along a stream, thirty-five miles south of Twin Falls. It was quite small and the occupants, all workers, were sluggish and unoffensive.

\section{Myrmica brevinodis Emery}

Three nests of this species, which is rather abundant in the Middle West, were beneath rocks in a very moist Agropyron repens area near Twin Falls.

\section{M. brevinodis sulcinodoides Emery}

Several colonies of this variety were beneath rocks in Hordeum jubatum areas along streams at Twin Falls. The workers were abundant and very sluggish. Winged forms appeared in the nests during early July.

13. Aphaenogaster uinta Wheeler

Six large colonies of uinta nested beneath rocks in the moist Snake River Canyon, near Twin Falls. Only the workers were found, all of whch were very timid.

\section{A. subterranea occidentalis Emery}

This variety is rather commonly distributed in moist areas, where it builds small nests beneath rocks. Winged forms apear in July and August, depending upon the locality.

\section{Stenamma brevicorne var.}

This undetermined variety of brevicorne is of lesser importance in the Twin Falls area, where it occupies very minute nests near streams or in other moist habitats.

\section{Crematogaster lineolata var. (near cerasi Fitch)}

Large colonies of this ant abounded beneath flat rocks throughout the semidesert area, being more numerous, however, in rather moist places. Each colony contained many queens. Winged forms appeared in late June near Twin Falls.

\section{Dorymyrmex pyramicus Roger}

Nests of this species were found in limited numbers near 
Twin Falls, occupying small, flat crater-nests of fine sand, in open areas of the sagebrush semidesert, and occasionally on the faces and in the denuded areas of mounds of Pogonomyrmex occidentalis Cresson.

\section{Tapinoma sessile Say}

Large colonies of this very common and well known ant are beneath rocks in moist places. Winged sexes appear in late June at Twin Falls.

19. Iridomyrmex pruinosus var.

Populous colonies of very active workers of an undescribed variety of pruinosus were found near Hagerman, inhabiting aggregated crater nests of fine sand in an area of greasewood.

20. Lasius niger americanus Emery

This very common occupant of the more moist areas throughout the state, nests beneath fallen timber or rocks, and more rarely occupies small, rude crater-nests of earth or sand. The workers are abundant and much brood develops into winged forms throughout June, July and August, depending upon the location of the nests. The ants are secretivorous and in some cases also scavengeristic.

21. L. niger sitkaënsis Pergande

Although less common than the variety, americanus, sitkaënsis is, nevertheless, a rather frequent occupant of moist places. Its nests and habitats are almost identical with those of americanus.

\section{L. umbratus mixtus aphidicola Walsh}

This variety lives beneath stones in very moist areas throughout the Snake River Plains. Its food consists chiefly of secretions from aphids and coccids which are attended in the nests.

\section{Polyergus rufescens breviceps Emery}

Only one nest of this species, which contained many workers of Formica fusca subsericea ${ }^{1}$, was observed by the writer.

${ }^{1}$ Slave complex. 
It was beneath a large flat rock on a dry sagebrush-covered hillslope in the Snake River Canyon, near Twin Falls.

24. Myrmecocystus melliger semirufus var.

Numerous crater nests, about six inches in diameter, predominated in a semidesert sand dune area near Indian Cove, and have also been found on sand hills near Buhl. The populous colonies contained both males and females in early June at Indian Cove. Repletes were not present.

25. M. yuma Whlr.

Many small crater nests of fine sand were found on a sagebrush plain near Hammett. The workers were very active. Winged forms appear in the nests during early July. Repletes were not found.

26. M. mexicanus var.

Sandy crater nests of an undescribed variety of mexicanus abounded in a sandy area near Indian Cove. Other localities include Hollister and Twin Falls. Males and females appeared in the nests in early June near Indian Cove and in late June near Twin Falls. True repletes were not present in the nests.

27. Camponotus maculatus vicinus nitidiventris Emery

This variety abounds beneath rocks in the more moist places of the sagebrush plains and in wooded areas of aspen and western yellow pine at higher elevations. The colonies are large and the workers active. Males and females appear in the nests throughout June and July near Twin Falls. I have taken this ant as far north as Boise.

28. C. hyatti Emery

A very few colonies of this species were beneath rocks on racher moist sagebrush and bromegrass-covered hillslopes near Twin Falls.

29. C. modoc Whlr.

This species is abundant in pine and aspen groves south of Rogerson. It inhabits nests in moist, rotting logs. 
30. Formica rufa obscuripes Forel

This ant is a very common occupant of the Snake River Plains, where, as populous colonies, it inhabits large thatched mounds, usually surrounding plants of sagebrush. It has been taken by the writer as far north as Stanley, where it is replaced by the variety melanotica Emery. Winged sexes appear during late June near Twin Falls.

31. F. subpolita Mayr.

Common to the semidesert plains and occurring throughout the state, this species is found inhabiting nests beneath rocks, and less commonly small crater mounds. Winged forms appear in early July at Twin Falls. Coccids and pseudoscorpions have been removed from nest chambers.

32. F. subpolita camponoticeps Whlr.

This variety is of less common occurrence than is the typical species but, nevertheless, very often nests beneath rocks under similar conditions and in the same localities as the typical subpolita. Workers were infested with the fungus Laboulbenia formicarum Thaxter.

33. $\quad F$. fusca neorufibarbis Emery

$F$. neorufibarbis lives beneath rocks or in earthen mounds in rather moist, shady and grassy areas throughout the Snake River plains. It feeds chiefly on honeydew and dead insects.

34. F. fusca subsericea Say

This very common ant is found in practically all parts of the region where it inhabits nests beneath rocks or occupies large earthen mounds.

35. F. fusca subaenescens Emery

$F$. subænescens is more rare than is subsericea and occupies more moist habitats. Where found, the nests are beneath large rocks. The an thas been collected near Twin Falls and Stanley.

36. F. neogagates Emery

A few nests of this species have been found by the writer 
in a deep canyon near Twin Falls. These were rather small and were beneath rocks on moist hillslopes covered with bunchgrass (Agropyron sp.).

37. $\quad F$. sanguinea subnuda Emery

Nests of subnuda were found, although rather infrequently, from the southern border of the state northward to Boise. The small colonies, in which abounded workers of $F$. fusca subsericea as slaves, were beneath large rocks in moist sagebrush areas.

38. F. sanguinea puberula Emery

Several small colonies of this ant were observed near Nampa, on the sagebrush plains. Many of the adults were infected with the fungus, Laboulbenia formicarum Thaxter.

39. F. oreas comptula Wheeler

Three nests of this rather uncommon ant were found by the writer near Rogerson, beneath large flat rocks on a sagebrush-covered hillslope. Winged forms appeared in early July. Each of the nests contained two or three beautiful golden-yellow queens.

40. F. lasioides vetula Whlr.

Several colonies of this ant were found at the upper limits of the Snake River Plains. The ants live beneath rocks in moist areas of abundant vegetation. 

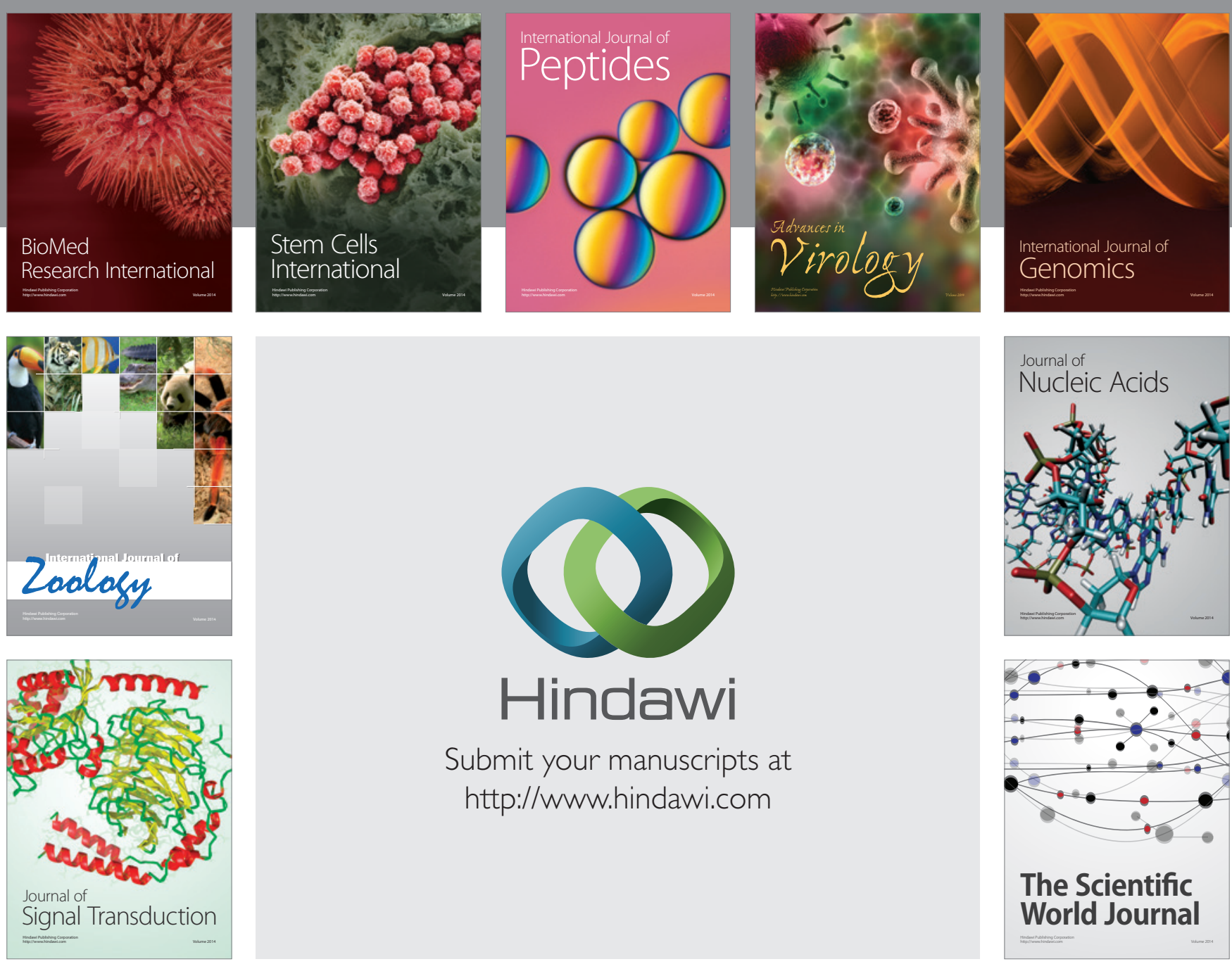

Submit your manuscripts at

http://www.hindawi.com
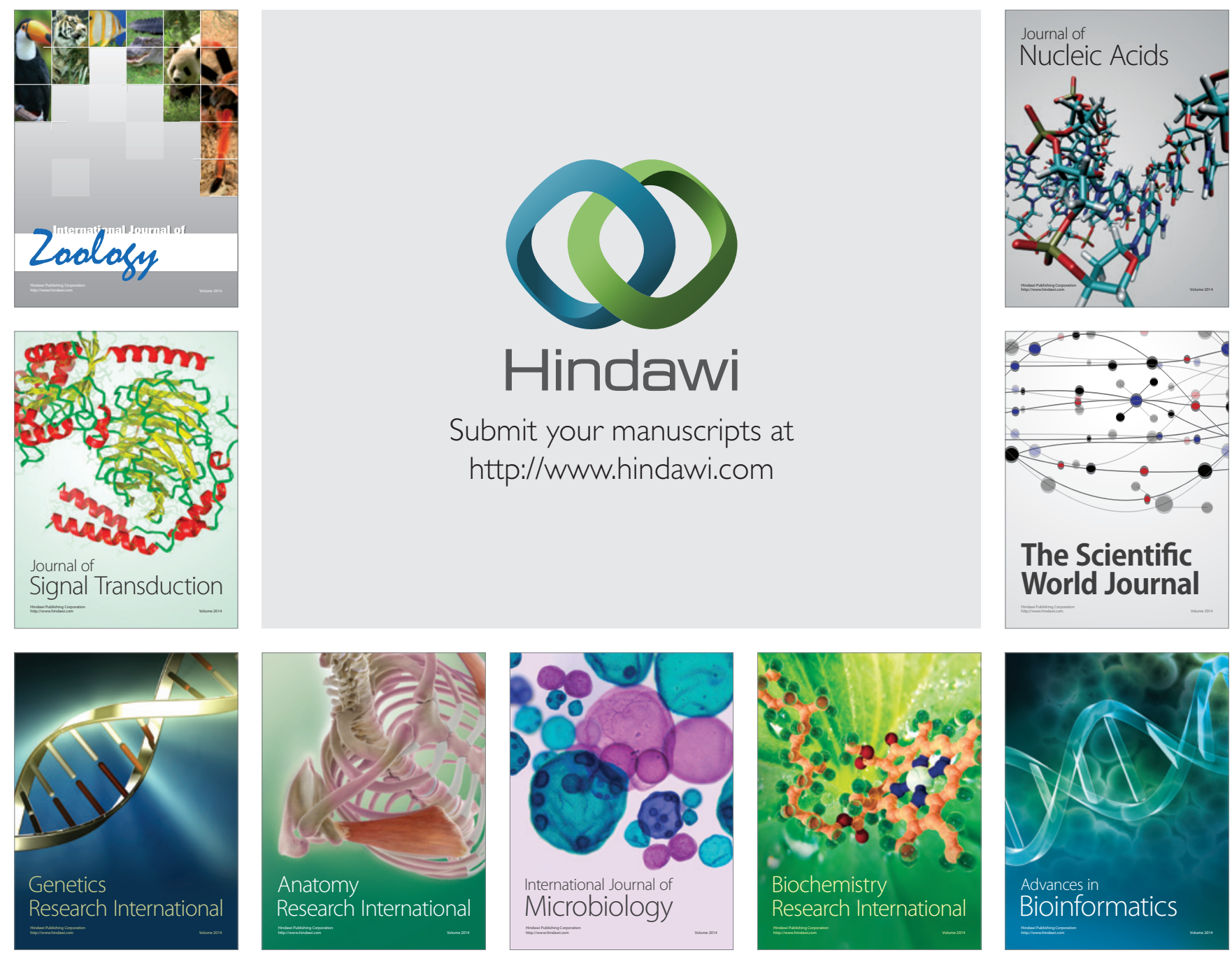

The Scientific World Journal
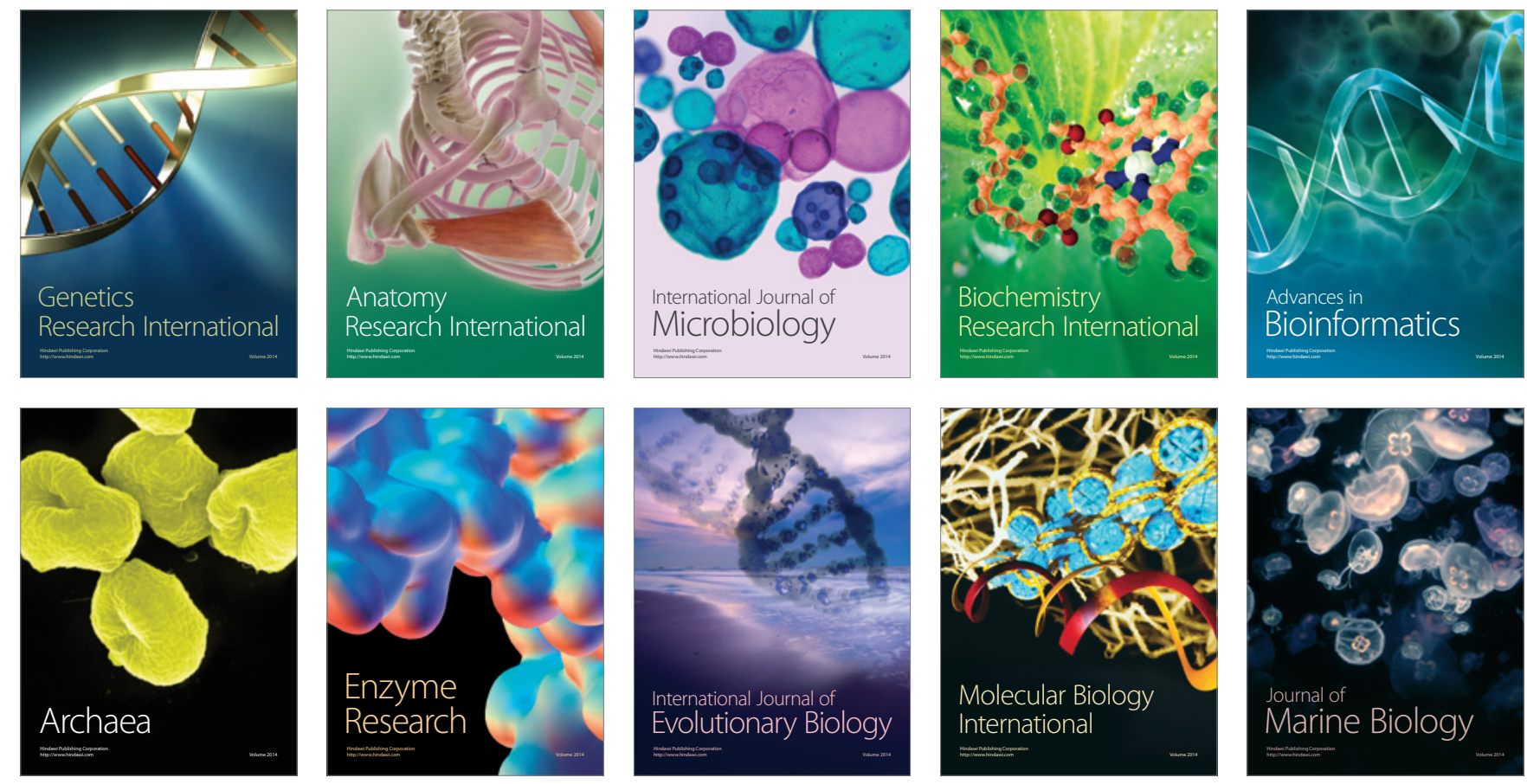